\title{
Konsep Kebenaran Allah Menurut Rasul Paulus di dalam Surat Roma
}

\author{
David Alinurdin* \\ *Penulis memperoleh gelar M.Div. dari STT SAAT (Seminari Alkitab Asia Tenggara) (2008) dan M.Th. \\ dari STT Amanat Agung (2016); saat ini melayani sebagai dosen teologi sistematika di STT SAAT
}

Email: asiunk.david@gmail.com

\begin{abstract}
Abstrak: Bagaimana Allah membenarkan orang-orang percaya di dalam proses keselamatan masih menjadi perdebatan di dalam kekristenan. Ada golongan yang berpandangan tindakan pembenaran Allah bersifat forensik dengan mengimputasikan kebenaran Kristus kepada seorang percaya sehingga ia mendapatkan status benar di hadapan Allah. Ada pula yang berpandangan pembenaran Allah itu bersifat moral dan transformatif dengan mengimpartasikan kebenaran Kristus di dalam diri orang percaya. Dan belakangan ini muncul pandangan New Perspective on Paul (NPP) yang merombak konsep pembenaran Allah tidak lagi bersifat forensik maupun etis, melainkan bersifat eklesiologis dengan memasukkan orang percaya di dalam komunitas umat Allah. Tulisan ini mengupas beberapa perikop kunci dari surat Paulus kepada jemaat di Roma guna memperlihatkan bahwa konsep kebenaran Allah dan karya pembenaran-Nya yang dipahami Paulus bersifat menyeluruh mencakup ketiga aspek tersebut.
\end{abstract}

Kata-kata kunci: Kebenaran Allah, Pembenaran, Surat Roma, Paulus

Abstract: How God justifies believers in the process of salvation is still under debate within Christianity. There are groups who view God's justification as forensic by imparting the truth of Christ to a believer so that the believer attains a right status before God. Some view God's justification as moral and transformative by imparting the truth of Christ in believers. And lately there is a New Perspective on Paul (NPP) that envisions overhauling the concept of God's justification in that it is neither forensic nor moral, but is ecclesiological by including believers in the community of God's people. This paper examines some key passages from Paul's letter to the church in Rome to show that the concept of God's truth and his justification, as understood by Paul, is comprehensive in that it encompasses all three aspects.

Keywords: Righteousness of God, Justification, Romans, Paul 


\section{Pendahuluan}

Dalam kekristenan, ada debat intens mengenai konsep kebenaran Allah (the righteousness

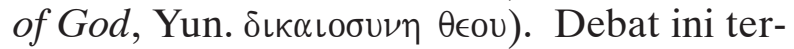
utama berkaitan dengan natur dan dampak dari kebenaran Allah itu kepada orang-orang percaya. Secara umum ada tiga macam penafsiran terhadap makna kebenaran Allah ini. Pertama, kebenaran Allah dikaitkan dengan status orang percaya di hadapan Allah. Dalam hal ini kata $\theta \in o u$ dipahami dalam bentuk genitif sumber (kebenaran yang berasal dari Allah). Kebenaran adalah status pemberian Allah kepada orang berdosa sehingga ia dinyatakan benar di hadapan Allah. Golongan Protestan tradisional yang memegang teguh pandangan ini mengatakan bahwa kebenaran Allah adalah tindakan Allah secara forensik (sebagai hakim yang secara hukum) membenarkan orang berdosa dengan cara mengambil dan menimpakan dosa-dosanya kepada Kristus yang tersalib sehingga utang dosanya diperhitungkan kepada Kristus, dan sebaliknya, juga mengimputasikan (mengambil dan mengenakan) ketaatan Kristus kepada orang berdosa tersebut sedemikian rupa sehingga kebenaran Kristus diperhitungkan kepadanya. ${ }^{1}$ Kedua, golongan Roma Katolik umumnya berpandangan bahwa kebenaran Allah itu bersifat etis atau moral, yaitu transformasi yang Allah kerjakan di dalam hidup orang percaya. Pandangan kedua ini lebih dikenal sebagai impartasi (menanamkan, memasukkan) kebenaran Kristus ke dalam diri orang percaya.

Meski demikian, pembedaan di atas terlalu menyederhanakan perdebatan yang ada. Kesulitan untuk memahami kebenaran Allah semakin bertambah ketika kita melihat penggunaannya di kitab lain dari Perjanjian Baru. Misalnya penulis Injil Matius menggunakan kata "kebenaran" sebagai tuntutan etika Kerajaan Allah $(5: 10,20 ; 6: 1,33)$ dan

${ }^{1}$ Pandangan tradisional mengenai pembenaran Allah ini dikenal sebagai doktrin imputasi (imputation). Lihat juga tulisan Richard D. Phillips, "A Justification of Imputed Righteousness," dalam By Faith Alone: Answering the Challenges to the Doctrine of Justification, ed. Gary L.W. Johnson dan Guy P. Waters (Wheaton: Crossway, 2006), 75-98. juga sebagai pemenuhan dari aktivitas penyelamatan Allah (3:15; 5:6; 21:32). ${ }^{2}$ Lebih lanjut, golongan Roma Katolik tidak murni memandang kebenaran Allah hanya bersifat etika saja dan juga tidak mengabaikan aspek forensik dan anugerah Allah, serta sebaliknya ada pula dari golongan Protestan tradisional yang memandang kebenaran Allah secara non-imputasi ${ }^{3}$ dan menekankan transformasi internal lebih kuat dari golongan Katolik (misalnya Pietisme Protestan di abad ke-17 dan 18). ${ }^{4}$

Namun, modifikasi yang lebih radikal lagi terhadap makna kebenaran Allah datang dari golongan New Perspective on Paul (NPP). Dimulai dari esai Krister Stendahl ${ }^{5}$ yang inovatif, kemudian diikuti oleh tulisan E.P. Sanders, ${ }^{6}$ James Dunn ${ }^{7}$ dan N.T. Wright,${ }^{8}$ NPP menantang golongan tradisional untuk mengevaluasi kembali konsep kebenaran Allah dan pembenaran oleh iman menurut Paulus. Menurut NPP, konsep kebenaran Allah dan pembenaran oleh iman perlu ditempatkan kembali dalam konteks Yudaisme abad pertama, bukan dalam konteks perdebatan pada

${ }^{2}$ D.A. Hagner, "Righteousness in Matthew's Theology," dalam Worship, Theology, and Ministry of the Early Church, ed. Michael J. Wilkins dan Terence Paige (Sheffield: JSOT, 1992), 101-102.

${ }^{3}$ Misalnya Robert H. Gundry, "The Nonimputation of Christ's Righteousness," dalam Justification: What's at Stake in Current Debates, ed. Mark Husbands dan Daniel J. Treier (Downers Grove: IVP, 2004), 17-45. Lihat juga artikel yang ditulis Gundry, "Why I Didn't Endorse The Gospel of Jesus Christ: An Evangelical Celebration" dalam Books and Culture dari Christianity Today (http:// www.booksandculture.com/articles/2001/janfeb/1.6.htm1?paging $=$ off. Diakses 23 April 2015).

${ }^{4}$ Douglas A. Campbell, The Rhetoric of Righteousness in Romans 3:21-26, JSNT Supplement Series (Sheffield: JSOT, 1992), 140.

${ }^{5}$ Krister Stendahl, Paul Among Jews and Gentiles (Minneapolis: Fortress, 1976).

${ }^{6}$ E.P. Sanders, Paul and Palestinian Judaism (Minneapolis: Fortress, 1977).

${ }^{7}$ James D.G. Dunn, The New Perspective on Paul (Grand Rapids, Eerdmans, 2007).

${ }^{8}$ N.T. Wright, What Saint Paul Really Said (Grand Rapids: Eerdmans, 1997) dan Justification: God's Plan and Paul's Vision (Downers Grove: IVP, 2009). 
abad ke-5 di Afrika Utara atau abad ke-16 di Eropa. ${ }^{9}$ Hasilnya adalah kebenaran Allah tidak lagi dimaknai sebagai tindakan Allah secara forensik membenarkan individu orang berdosa melainkan sebagai kesetiaan Allah kepada perjanjian-Nya. NPP memandang kebenaran Allah bukan lagi sebagai kebenaran yang diterima orang berdosa melalui iman di dalam Kristus, melainkan sebagai penerimaan Allah ke dalam komunitas umat-Nya. Maka, NPP sudah menggeser isu utama pembenaran Allah bukan lagi di dalam kerangka soteriologis tetapi eklesiologis, bukan tentang keselamatan melainkan tentang komunitas umat Allah. Wright mengatakannya demikian,

Justification in the first century was not about how someone might establish a relationship with God. It was about God's eschatological definition, both future and present, of who was, in fact, a member of his people. In Sander's term, it was not so much about 'getting in', or indeed about 'staying in', as about 'how you could tell who was in'. In standard Christian theology language, it wasn't so much about soteriology as about ecclesiology; not so much about salvation as about the church. ${ }^{10}$

Karena perdebatan di atas, maka tulisan ini bermaksud untuk memaparkan dan menjelaskan konsep kebenaran Allah menurut Paulus, dan sekaligus juga memberikan solusi jalan tengah di antara ketiga perbedaan pandangan di atas. Untuk itu, latar belakang pemikiran Paulus sebagai orang Yahudi perlu diperhatikan. Di bagian selanjutnya kita akan melihat konsep kebenaran Allah di dalam Perjanjian Lama. ${ }^{11}$

${ }^{9}$ J.V. Fesko, Justification: Understanding the Classic Reformed Doctrine (Phillipsburg: P\&R, 2008), 211.

${ }^{10}$ Wright, What Saint Paul Really Said, 119.

${ }^{11}$ Untuk penyebutan selanjutnya disebut PL.

\section{Konsep Kebenaran Allah di dalam Perjanjian Lama}

Pemahaman Paulus tentang kebenaran Allah dibentuk oleh PL, yang menjadi konteks dan latar belakang pemikiran teologisnya. Dalam PL, "kebenaran Allah" setidaknya memiliki tiga makna yang saling terkait, yaitu: (1) kesetiaan Allah terhadap perjanjian-Nya dengan Israel; (2) keadilan Allah, khususnya bagi kaum miskin dan tak berdaya; dan (3) kuasa penyelamatan Allah yang bersifat eskatologis untuk memulihkan segala sesuatu.

\section{Kebenaran Allah sebagai Kesetiaan-Nya kepada Perjanjian dengan Israel}

Di dalam Septuaginta (LXX), versi Yunani

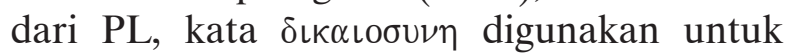
menerjemahkan kata Ibrani צדק. Kata Ibrani ini memiliki arti dasar sebagai kesetiaan di dalam sebuah relasi yang menjamin ketenteraman dan kepercayaan. ${ }^{12}$ Tindakan yang "benar" atau dilakukan "dalam kebenaran" adalah tindakan yang dilakukan "dalam relasi yang benar" dengan rekan perjanjian. ${ }^{13}$ Misalnya, ketika Yehuda berkata tentang Tamar di dalam Kejadian 38:26 bahwa "perempuan itulah yang benar" maka yang dimaksud bukanlah Tamar benar secara moral, melainkan Tamar melakukan hal yang benar dalam hal relasinya dengan Yehuda. Contoh lainnya adalah dalam 1 Samuel 24:18, ketika Saul berkata kepada Daud, "Engkau lebih benar dari pada aku" maka yang dimaksudkan Saul adalah dalam konteks kesetiaan Daud memenuhi kewajiban relasionalnya terhadap Saul (yaitu menolak melakukan hal yang jahat terhadap rajanya sendiri yang telah diurapi TUHAN) sementara Saul sendiri menyadari dirinya gagal untuk memenuhi kewajiban relasionalnya terhadap Daud (yaitu sebagai raja yang seharusnya bersikap adil dan benar). ${ }^{14}$

\footnotetext{
${ }^{12} \mathrm{~A}$. Katherine Grieb, The Story of Romans: A Narrative Defense of God's Righteousness (Louisville: WJK, 2002), 21.

${ }^{13}$ Ibid., 21.

${ }^{14}$ James D.G. Dunn, The Theology of Paul the Apostle (Grand Rapids: Eerdmans, 1998), 341-342.
} 
Ketika Allah dikatakan sebagai Allah yang benar (righteous) maka hal itu berarti Allah dapat dipercaya dan diandalkan kesetiaanNya. Para nabi di PL sering kali menggunakan analogi pernikahan untuk menjelaskan kesetiaan Allah kepada relasi perjanjian-Nya dengan Israel. Nyanyian kemenangan Debora atas Sisera dalam Hakim-hakim 5:11 yang menyebutkan tentang "perbuatan TUHAN yang adil" mengacu kepada tindakan penyelamatan Allah sebagai bukti kesetiaan-Nya kepada umat-Nya. Yesaya 51:4-5 juga menjelaskan kaitan yang erat antara tindakan penyelamatan Allah dengan kebenaran-Nya, yang menunjukkan bahwa pembebasan yang Allah lakukan terhadap umat-Nya adalah wujud dari komitmen kesetiaan-Nya kepada relasi perjanjian-Nya dengan mereka. ${ }^{15}$ Michael F. Bird menyatakan bahwa manifestasi atau perwujudan paling tinggi dari kebenaran Allah adalah di dalam perjanjian dengan Israel dan dengan memberikan hukum Taurat sebagai peraturan perjanjian. ${ }^{16}$

\section{Kebenaran Allah sebagai Keadilan Allah, Sang Hakim yang Benar}

Makna kedua dari kebenaran Allah berasal dari latar belakang sidang pengadilan hukum (law court). Hal ini sering disebut sebagai kebenaran secara forensik. Di dalam PL, metafora secara hukum ini dapat berfungsi di dalam tiga cara. Pertama, Allah digambarkan sebagai pendakwa. Allah yang setia mengadakan perkara terhadap umat manusia yang tidak setia (misalnya Mzm. 143:2; Yes. 5:3-4; 43:9, 26). Kedua, Allah digambarkan sebagai hakim yang adil yang menyatakan keadilan-Nya sebagai sebuah keputusan secara

${ }^{15}$ Douglas Moo mengatakan bahwa di dalam beberapa teks Perjanjian Lama, kebenaran Allah dimengerti sebagai dasar atau motivasi dari tindakan penyelamatan Allah, yaitu kesetiaan-Nya atau komitmen-Nya untuk memenuhi janji-Nya kepada umat-Nya (Douglas J. Moo, NICNT: The Epistle to the Romans [Grand Rapids: Eerdmans, 1996], 82).

${ }^{16}$ Michael F. Bird, The Saving Righteousness of God: Studies on Paul, Justification, and the New Perspective (Eugene: Wipf \& Stock, 2007), 11. yuridis. ${ }^{17}$ Sebagai hakim, Allah mendengarkan bukti-bukti dari kedua kubu yang bertikai dan kemudian membuat keputusan yang adil dengan menentukan siapa yang benar dan salah (1Raj. 8:31-32; 2Taw. 6:23; bdk. Ul. 25:1; 2Sam. 15:4; Ams. 17:15; Yes. 5:22-23).

Ketiga, Allah digambarkan sebagai hakim yang adil yang memberikan keadilan dan membela kaum tertindas. Dari pemahaman di atas maka terlihat bahwa aspek sosial dari keadilan Allah juga dinilai sebagai hal yang penting. Allah sebagai hakim yang adil bertindak sesuai hukum untuk membela kaum miskin dan tak berdaya serta menghukum para penindas dan orang-orang yang jahat. Pemahaman ini juga dilatarbelakangi oleh relasi perjanjian antara Allah dengan Israel. Jika kaum Israel bertindak salah terhadap sesamanya, Allah akan menyatakan keadilan dan penghakiman-Nya terhadap mereka. Nabi Amos menyatakan bahwa karena Israel memiliki relasi khusus dengan Allah dibandingkan dengan bangsa-bangsa lain, maka Allah juga akan menghakimi Israel dengan lebih keras dibandingkan terhadap bangsabangsa lain (Am. 3:2). ${ }^{18}$

\section{Kebenaran Allah sebagai Kuasa-Nya yang Membuat Segala Sesuatunya Menjadi Benar di Akhir Zaman}

Selama dan setelah masa pembuangan Israel di Babel, aspek kebenaran Allah yang berupa penyelamatan secara eskatologis mendapatkan penekanan yang penting. Di dalam Mazmur (mis. pasal 96 dan 98) dan Yesaya 40-66, frase "kebenaran Allah" menggambarkan tindakan penyelamatan Allah terhadap umatNya Israel. ${ }^{19}$ Kasemann mengatakan bahwa kebenaran Allah hampir menjadi istilah teknis dalam apokaliptik Yahudi untuk menyatakan kesetiaan Allah yang menyelamatkan Israel dan bangsa-bangsa lain, yaitu Allah digambarkan sebagai hakim yang adil atas seluruh

\footnotetext{
${ }^{17} \mathrm{Grieb}$, The Story of Romans, 23.

${ }^{18}$ Ibid.

${ }^{19}$ Ibid.
} 
bumi. $^{20}$ Allah akan membuat benar atau memperbaiki (put right) relasi Israel dengan bangsa-bangsa lain. ${ }^{21}$ Dia akan menghadirkan keadilan dan kedamaian di seluruh dunia. Israel memahami pembuangannya di Babel dalam konteks eksodus dari Mesir. Jadi, sama seperti Allah telah bertindak menyelamatkan mereka dari tentara Firaun maka Allah akan sekali lagi melakukan intervensi di dalam sejarah umat manusia untuk menyelamatkan Israel dari pembuangan di Babel..$^{22}$

Tulisan-tulisan Yahudi apokaliptik pada masa antarperjanjian meneruskan tradisi kebenaran Allah yang ada di dalam Mazmur dan Yesaya 40-66, dengan menekankan kuasa Allah Sang Pencipta yang bertindak menyelamatkan ciptaan-Nya yang terhilang karena kuasa musuh yang menindas, yaitu dosa dan kematian yang masuk ke dalam dunia karena ketidaktaatan Adam dan Hawa. ${ }^{23}$ Allah akan menyelamatkan ciptaan yang telah diperbudak oleh dosa dan kematian tersebut. Tulisan-tulisan apokaliptik ini (misalnya Naskah Laut Mati dari Qumran) memperlihatkan kombinasi antara keputusasaan terhadap kemungkinan manusia dibenarkan dengan kerinduan yang besar akan penyelamatan eskatologis dari Allah. ${ }^{24}$

\section{Konsep Kebenaran Allah Menurut Rasul Paulus}

Dengan melihat latar belakang pemahaman Yahudi di atas mengenai konsep kebenaran Allah, maka sepertinya Paulus pun mengartikan kebenaran Allah sebagai (1) karakter Allah yang benar dan adil secara forensik; (2) kesetiaan Allah kepada relasi perjanjian dengan umat-Nya; dan (3) tindakan penyelamatan Allah secara eskatologis untuk

\footnotetext{
${ }^{20}$ Ernst Kasemann, Commentary on Romans, diterjemahkan oleh G.W. Bromiley (Grand Rapids: Eerdmans, 1980), 23-30, seperti dikutip oleh Grieb, The Story of Romans, 23-24. Lihat juga Moo, The Epistle to the Romans, 88.

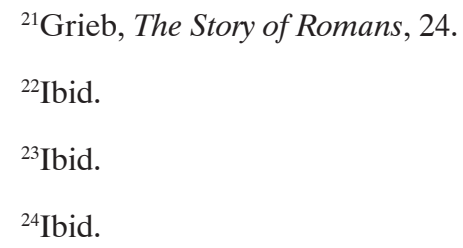

memulihkan segala sesuatu di alam semesta ini sebagai wujud kesetiaan-Nya kepada perjanjian dengan umat-Nya. Meski demikian, pengalaman perjumpaan-Nya dengan Yesus Kristus yang bangkit telah mengubah paradigmanya akan konsep kebenaran Allah. Sekarang Paulus melihat bahwa Allah yang karakter-Nya benar-adil itu akan bertindak sesuai karakter-Nya itu dengan melakukan tindakan penyelamatan eskatologis melalui kematian dan kebangkitan Yesus Kristus, sebagai wujud kesetiaan-Nya kepada perjanjian dengan umat-Nya. Pemahaman Paulus akan konsep kebenaran Allah yang demikian terlihat di dalam beberapa perikop dari surat Roma yang akan digali berikut ini.

\section{Roma 1:16-17}

${ }^{16}$ Sebab aku mempunyai keyakinan yang kokoh dalam Injil, karena Injil adalah kekuatan Allah yang menyelamatkan setiap orang yang percaya, pertama-tama orang Yahudi, tetapi juga orang Yunani. ${ }^{17}$ Sebab di dalamnya nyata kebenaran Allah, yang bertolak dari iman dan memimpin kepada iman, seperti ada tertulis: "Orang benar akan hidup oleh iman."

Secara umum para sarjana mengakui bahwa perikop ini adalah perikop sentral di dalam surat Roma, karena menentukan penafsiran terhadap seluruh isi surat tersebut. ${ }^{25}$ Perikop ini tentu tidak bisa dilepaskan dari konteksnya, ayat $8-15$, yang menjelaskan tujuan utama Paulus untuk memberitakan Injil di Roma. Di dalam perikop inilah Paulus menjelaskan Injil seperti apakah yang rindu untuk diberitakannya. Injil tersebut adalah kuasa Allah yang menyelamatkan orang percaya, yang dari dalamnya disingkapkan kebenaran Allah. Apakah arti "kebenaran Allah" di perikop ini? Disandingkannya kata "percaya" (16) dan "iman" (17) dengan frasa "kebenaran Allah" mengindikasikan bahwa seorang percaya dibenarkan karena imannya dan hidup oleh imannya tersebut. Jika kebenaran dikaitkan dengan iman atau percaya maka yang menjadi fokus perhatian di sini adalah

${ }^{25}$ Thomas R. Schreiner, BECNT: Romans (Grand Rapids: Baker, 1998), 58. 
status seseorang di hadapan Allah. ${ }^{26}$ Kata $\theta \in o u$ di sini dipahami dalam bentuk genitif sumber. Dengan demikian, kebenaran Allah dipahami secara forensik sebagai pemberian Allah dan deklarasi Allah kepada manusia berdosa sedemikian rupa sehingga ia berstatus sebagai orang benar.

Namun di sisi lain, frasa "kebenaran Allah" juga dapat dipahami sebagai aktivitas Allah yang mengubahkan hidup orang percaya. Kata $\theta \in o u$ di sini dipahami dalam bentuk genitif subjektif. Mereka yang berpandangan seperti ini bukan berarti menolak kebenaran secara forensik sebagai status yang diberikan oleh Allah, tetapi juga menekankan bahwa kebenaran Allah lebih dari sekadar status benar. $^{27}$ Kebenaran Allah dipahami baik secara forensik maupun secara efektif. Pemahaman ini didukung oleh kata "nyata" (disingkapkan, $\alpha \pi о \kappa \alpha \lambda \cup \pi \tau \epsilon \tau \alpha$ ) yang mengacu kepada aktivitas Allah secara eskatologis yang masuk ke dalam sejarah, dan semakin diperkuat dengan paralelisme antara ayat 17 dan 18 . Kata "nyata" (disingkapkan) yang digunakan di ayat 17 diulangi kembali penggunaannya di ayat 18 namun dengan subjek yang berbeda. Sama seperti murka Allah dideskripsikan sebagai aktivitas ilahi maka kebenaran Allah pun mengacu kepada aktivitas Allah. ${ }^{28}$ Kehadiran kata $\sigma \omega \tau \eta \rho\llcorner\alpha$ (keselamatan) di ayat 16 semakin memperkuat nuansa karya penyelamatan eskatologis ilahi di dalam frasa "kebenaran Allah." 29

Dengan demikian, frasa "kebenaran Allah" di dalam perikop ini dapat dipahami (1) secara forensik sebagai status benar yang Allah berikan kepada manusia berdosa, dan (2) secara efektif sebagai aktivitas Allah yang berkuasa menyelamatkan dan mengubahkan kehidupan orang percaya. Dua sisi makna

\section{${ }^{26}$ Ibid., 64.}

${ }^{27}$ Ibid., 63. Teolog-teolog yang memegang pandangan ini adalah seperti Kasemann dan para pengikutnya seperti Stuhlmacher, Muller, Kertelge, Ziesler, Althaus, Wilckens, Dunn, Garlington, Stott dan Wenham.

${ }^{28}$ Ibid., 65.

${ }^{29}$ Campbell, The Rhetoric of Righteousness, 160. kebenaran Allah yang ada di ayat ini tidak bisa dipisahkan dan sulit dibedakan secara kronologis mana yang lebih dahulu dan mana yang belakangan. Yang dapat dipastikan adalah kebenaran Allah yang menyelamatkan itu melakukan dua hal kepada manusia, yaitu memulihkan relasinya dengan Allah (aspek forensik) dan mengubahnya menjadi manusia baru (aspek efektif atau etika). ${ }^{30}$

\section{Roma 3:21-26}

${ }^{21}$ Tetapi sekarang tanpa hukum Taurat kebenaran Allah telah dinyatakan, seperti yang disaksikan dalam Kitab Taurat dan Kitabkitab para nabi, ${ }^{22}$ yaitu kebenaran Allah karena iman dalam Yesus Kristus bagi semua orang yang percaya. Sebab tidak ada perbedaan. ${ }^{23}$ Karena semua orang telah berbuat dosa dan telah kehilangan kemuliaan Allah, ${ }^{24}$ dan oleh kasih karunia telah dibenarkan dengan cumacuma karena penebusan dalam Kristus Yesus. ${ }^{25}$ Kristus Yesus telah ditentukan Allah menjadi jalan pendamaian karena iman, dalam darahNya. Hal ini dibuat-Nya untuk menunjukkan keadilan-Nya, karena Ia telah membiarkan dosa-dosa yang telah terjadi dahulu pada masa kesabaran-Nya. ${ }^{26}$ Maksud-Nya ialah untuk menunjukkan keadilan-Nya pada masa ini, supaya nyata, bahwa Ia benar dan juga membenarkan orang yang percaya kepada Yesus."

Para sarjana pada umumnya sepakat bahwa perikop ini adalah bagian yang krusial dari surat Roma karena dapat disebut sebagai jantung dari surat ini. ${ }^{31}$ Frasa "kebenaran Allah" muncul 4 kali (ay. 21, 22, 25, 26, dengan "keadilan-Nya" di dua ayat terakhir). Setelah di bagian sebelumnya (1:18-3:20) Paulus menyatakan kebutuhan besar manusia berdosa akan kebenaran Allah, sekarang di perikop Paulus menjelaskan bagaimana kebenaran Allah itu memberi kuasa kepada Injil untuk menyatakan keselamatan bagi manusia berdosa.

${ }^{30}$ J.A. Ziesler, The Meaning of Righteousness in Paul: $A$ Linguistic and Theological Enquiry (Cambridge: Cambridge University Press, 2004), 188-189.

${ }^{31}$ Schreiner, Romans, 78-79. 
Perikop ini terdiri dari empat bagian. ${ }^{32}$ Pertama, Paulus mengulangi kembali penyingkapan kebenaran Allah dan mengaitkannya dengan Perjanjian Lama (ay. 21). Kedua, Paulus menyatakan bahwa semua orang sama-sama telah jatuh ke dalam dosa dan sama-sama punya akses kepada kebenaran Allah melalui iman (ay. 22-23). Ketiga, Paulus menekankan bahwa kebenaran Allah bersumber dari karya pengorbanan dan penebusan Kristus (ay. 24-25a). Dan terakhir, Paulus menunjukkan bahwa penebusan Kristus ditujukan bukan hanya untuk membenarkan orang berdosa melainkan juga dimaksudkan Allah untuk mendemonstrasikan sifat keadilannya (ay. 25b-26).

Frasa "kebenaran Allah" di sini dipahami, pertama, sebagai tindakan penyelamatan Allah secara eskatologis yang diaktualisasikan dalam sejarah umat manusia. ${ }^{33} \mathrm{Hal}$ ini terlihat dari penggunaan frasa "tetapi sekarang" ( $\nu \nu \nu \iota \delta \epsilon$ ) yang mengindikasikan kontras antara era lama (yang didominasi oleh dosa) dengan era baru yang ditandai dengan tibanya keselamatan eskatologis dari Allah. ${ }^{34}$ Pemahaman ini semakin diperkuat dengan frasa "telah dinyatakan" ( $\pi \epsilon \phi \alpha \nu \in \rho \omega \tau \alpha \iota$, yang berarti "dimanifestasikan," sinonim dengan kata $\alpha \pi \circ \kappa \alpha \lambda \cup \pi \tau \epsilon \tau \alpha \iota$ di 1:17) yang mengacu kepada demonstrasi tindakan Allah yang pasti dan tegas untuk menggenapi tujuan akhir-Nya bagi umat manusia. ${ }^{35}$ Kebenaran Allah ini tersedia bagi semua orang yang beriman di dalam Yesus Kristus, dan bukan karena melakukan hukum Taurat.

Kedua, kebenaran Allah di perikop ini juga dapat dipahami sebagai karakter benar dan adil sebagai milik Allah ( $\theta \in \mathrm{\epsilon u}$ dipahami sebagai genitif subjektif) yang kemudian secara forensik membenarkan orang percaya yang beriman di dalam Yesus Kristus. Pemahaman

\footnotetext{
${ }^{32}$ Moo, The Epistle to the Romans, 219.

${ }^{33}$ Schreiner, Romans, 180. Lihat juga Campbell, The Rhetoric of Righteousness, 158-159

${ }^{34} \mathrm{Moo}$, The Epistle to the Romans, 221.

${ }^{35}$ James D.G. Dunn, WBC: Romans 1-8 (Dallas: Word, 1998), Logos Library System.
}

ini didukung oleh penyebutan dua kali kata "keadilan-Nya" (ay. 25-26, yang menggunakan kata ganti milik autou) yang paralel dengan dua kali penyebutan frasa "kebenaran Allah" di ayat 21-22. ${ }^{36}$ Selain itu penggunaan kata kerja "dibenarkan" (ay. 24) dan "membenarkan" (ay. 26) memiliki makna forensik sebagai deklarasi dari Allah yang adil, menyatakan benar atau memberikan status benar kepada orang percaya. ${ }^{37}$ Disandingkannya kata "iman" dan "percaya" dengan frasa "kebenaran Allah" di ayat 22 semakin memperkuat pemahaman forensik terhadap "kebenaran Allah" sebagai status benar yang diterima orang percaya melalui iman di dalam Yesus Kristus. ${ }^{38}$

Kalimat "hal ini dibuat-Nya untuk menunjukkan keadilan-Nya, karena Ia telah membiarkan dosa-dosa yang telah terjadi dahulu pada masa kesabaran-Nya" pada ayat 25b diperdebatkan oleh dua pandangan. Mereka yang mengartikan frasa "menunjukkan keadilan-Nya" sebagai "membuktikan keadilanNya" memiliki pemahaman bahwa kebenaran

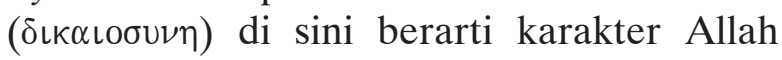
yang adil yang dinyatakan-Nya dengan tujuan untuk membuktikan bahwa tindakan-Nya yang adil sejalan dengan sifat-Nya yang adil. ${ }^{39}$ Sedangkan mereka yang mengartikan frasa "menunjukkan keadilan-Nya" sebagai "mendemonstrasikan kesetiaan-Nya yang menyelamatkan" memiliki pemahaman bahwa kebenaran di sini berarti kebenaran Allah yang bersifat menyelamatkan dan mengampuni dosa melalui karya penebusan Kristus sebagai wujud kesetiaan kepada perjanjian-Nya. ${ }^{40}$

Dari pembahasan di atas dapat disimpulkan bahwa frasa "kebenaran Allah" dipahami dari dua sisi, yaitu sebagai (1) atribut Allah yang benar dan adil yang kemudian secara forensik

${ }^{36}$ Campbell, The Rhetoric of Righteousness, 157.

${ }^{37}$ Moo, The Epistle to the Romans, 227-228. Lihat juga Schreiner, Romans, 189.

${ }^{38}$ Schreiner, Romans, 184-189.

${ }^{39}$ Ibid., 195; dan Moo, The Epistle to the Romans, 237.

${ }^{40}$ Schreiner, Romans, 196; dan Moo, The Epistle to the Romans, 238. 
membenarkan orang yang beriman kepada Kristus; dan juga sebagai (2) tindakan penyelamatan Allah secara eskatologis yang mengampuni dosa dan mengubahkan hidup melalui karya penebusan Kristus.

\section{Roma 4:1-16}

${ }^{1} J a d i$ apakah akan kita katakan tentang Abraham, bapa leluhur jasmani kita? ${ }^{2}$ Sebab jikalau Abraham dibenarkan karena perbuatannya, maka ia beroleh dasar untuk bermegah, tetapi tidak di hadapan Allah. ${ }^{3}$ Sebab apakah dikatakan nas kitab suci? "Lalu percayalah Abraham kepada Tuhan, dan Tuhan memperhitungkan hal itu kepadanya sebagai kebenaran." ${ }^{4}$ Kalau ada orang yang bekerja, upahnya tidak diperhitungkan sebagai hadiah, tetapi sebagai haknya. ${ }^{5}$ Tetapi kalau ada orang yang tidak bekerja, namun percaya kepada Dia yang membenarkan orang durhaka, imannya diperhitungkan menjadi kebenaran... ${ }^{9}$ Adakah ucapan bahagia ini hanya berlaku bagi orang bersunat saja atau juga bagi orang tak bersunat? Sebab telah kami katakan, bahwa kepada Abraham iman diperhitungkan sebagai kebenaran. ${ }^{10}$ Dalam keadaan manakah hal itu diperhitungkan? Sebelum atau sesudah ia disunat? Bukan sesudah disunat, tetapi sebelumnya. ${ }^{11}$ Dan tanda sunat itu diterimanya sebagai meterai kebenaran berdasarkan iman yang ditunjukkannya, sebelum ia bersunat. Demikianlah ia dapat menjadi bapa bagi semua orang percaya yang tak bersunat, supaya kebenaran diperhitungkan kepada mereka, ${ }^{12}$ dan juga menjadi bapa orang-orang bersunat, yaitu mereka yang bukan hanya bersunat, tetapi juga mengikuti jejak iman Abraham, bapa leluhur kita, pada masa ia belum disunat. ${ }^{13}$ Sebab bukan karena hukum Taurat telah diberikan janji kepada Abraham dan keturunannya, bahwa ia akan memiliki dunia, tetapi karena kebenaran, berdasarkan iman. . . . ${ }^{16}$ Karena itulah kebenaran berdasarkan iman supaya merupakan kasih karunia, sehingga janji itu berlaku bagi semua keturunan Abraham, bukan hanya bagi mereka yang hidup dari hukum Taurat, tetapi juga bagi mereka yang hidup dari iman Abraham. Sebab Abraham adalah bapa kita semua."
Dalam bagian pertama dari perikop ini (ay. 1-8) terlihat dengan jelas bahwa kebenaran Allah dipahami secara forensik sebagai status benar yang dianugerahkan Allah kepada orang percaya berdasarkan iman dan bukan berdasarkan perbuatan. Untuk menjelaskan hal ini, Paulus menggunakan contoh Abraham yang dibenarkan karena percaya kepada Allah dan bukan karena menaati hukum Taurat, yang ia kutip dari Kejadian 15:6. Kata kunci yang penting di sini adalah "memper-

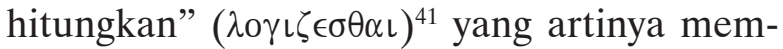
perhitungkan kepada seseorang apa yang secara inheren bukan miliknya. ${ }^{42}$ Dengan demikian, kebenaran Allah bukanlah pembawaan alamiah pada manusia melainkan kebenaran asing yang dianugerahkan kepada kita oleh anugerah Allah. ${ }^{43}$ Pemahaman bahwa kebenaran Allah ini bersifat forensik yang diimputasikan kepada orang berdosa semakin diperjelas di ayat 4-5 yang menganalogikan kebenaran Allah bukan seperti upah atas pekerjaan manusia melainkan seperti hadiah.

Namun demikian, kata kebenaran Allah di perikop juga mengandung makna sebagai kesetiaan Allah kepada perjanjian dengan umat-Nya. Hal ini terlihat di bagian kedua dari perikop ini, ayat 9-16. Pemahaman kebenaran Allah yang seperti ini dipakai Paulus dengan tujuan untuk memprotes nasionalisme dari orang-orang Yahudi yang mewajibkan orang-orang non-Yahudi untuk disunat terlebih dahulu supaya bisa menjadi bagian dari umat Allah. Untuk menyanggah konsep yang salah dari orang-orang Yahudi yang etnosentris ini, Paulus menggunakan Abraham-yang dianggap sebagai bapa leluhur umat Israelsebagai contoh dari orang yang dibenarkan karena iman dan bukan karena melakukan sunat (ay. 9-10). Paulus memahami sunat itu sebagai tanda meterai bahwa Abraham sudah dibenarkan terlebih dahulu berdasarkan iman sebelum ia bersunat (11a). Dengan argumen

\footnotetext{
${ }^{41}$ Disebut hingga 11 kali di pasal 4 ini (ay. 3, 4, 5, 6, 8, $9,10,11,22,23,24)$.

${ }^{42}$ Schreiner, Romans, 215; dan Moo, The Epistle to the Romans, 262.

${ }^{43}$ Schreiner, Romans, 215
} 
seperti ini maka Paulus dapat menegaskan Abraham sebagai bapa bagi semua orang yang percaya yang tak bersunat (yaitu nonYahudi) dan juga menjadi bapa bagi semua orang bersunat (yaitu Yahudi) yang mengikuti jejak iman Abraham sebelum ia disunat (ay. 11b-12). Dengan demikian terlihat bahwa pemahaman Paulus akan kebenaran Allah sebagai kesetiaan kepada perjanjianNya dipakai untuk membangun doktrin pembenarannya sebagai tindakan Allah untuk memasukkan orang-orang non-Yahudi ke dalam relasi perjanjian dengan-Nya untuk menjadi bagian dari umat perjanjian-Nya. Konsep kebenaran Allah sebagai kesetiaanNya kepada perjanjian dengan umat-Nya juga terlihat dari konteks pasal 4 ini, yaitu pasal 3:27-31 yang memperlihatkan Allah sebagai Allah bagi semua bangsa, tidak hanya untuk orang Yahudi tetapi juga bangsa-bangsa lain, yang membenarkan baik orang-orang bersunat karena iman, maupun orang-orang tak bersunat juga karena iman (29-30). ${ }^{44}$

Dengan melihat pemaparan di atas maka dapat disimpulkan bahwa dalam perikop ini Paulus menyatakan kebenaran Allah dari dua sisi, yaitu (1) secara forensik sebagai status benar yang Allah anugerahkan dan perhitungkan kepada orang percaya berdasarkan imannya; dan (2) sebagai kesetiaan Allah kepada perjanjian dengan umat-Nya yang tidak hanya terbatas untuk bangsa Israel saja tetapi juga semua orang dari bangsa-bangsa lain yang percaya dengan iman yang sama seperti iman Abraham, seperti yang telah dijanjikan Allah kepada Abraham bahwa melalui keturunan-Nya semua kaum di bumi akan mendapat berkat (Kej. 12:1-3). Melihat pemahaman kebenaran Allah yang seperti ini maka pembenaran memiliki dua fungsi ganda sebagai masuk ke dalam keselamatan dan menentukan keanggotaan di dalam umat Allah. Schreiner menegaskan bahwa kedua tema itu "belong indissolubly together" karena "Paul is interested in the inclusion of Gentiles and the basis of their inclusion." 45

${ }^{44}$ Dunn, The Theology of Paul the Apostle, 367.

${ }^{45}$ Schreiner, Romans, 228.

\section{Roma 5:15-19}

${ }^{15}$ Tetapi karunia Allah tidaklah sama dengan pelanggaran Adam. Sebab, jika karena pelanggaran satu orang semua orang telah jatuh di dalam kuasa maut, jauh lebih besar lagi kasih karunia Allah dan karunia-Nya, yang dilimpahkan-Nya atas semua orang karena satu orang, yaitu Yesus Kristus. ${ }^{16}$ Dan kasih karunia tidak berimbangan dengan dosa satu orang. Sebab penghakiman atas satu pelanggaran itu telah mengakibatkan penghukuman, tetapi penganugerahan karunia atas banyak pelanggaran itu mengakibatkan pembenaran. ${ }^{17}$ Sebab, jika oleh dosa satu orang, maut telah berkuasa oleh satu orang itu, maka lebih benar lagi mereka, yang telah menerima kelimpahan kasih karunia dan anugerah kebenaran, akan hidup dan berkuasa oleh karena satu orang itu, yaitu Yesus Kristus. ${ }^{18}$ Sebab itu, sama seperti oleh satu pelanggaran semua orang beroleh penghukuman, demikian pula oleh satu perbuatan kebenaran semua orang beroleh pembenaran untuk hidup. ${ }^{19} \mathrm{Jadi}$ sama seperti oleh ketidaktaatan satu orang semua orang telah menjadi orang berdosa, demikian pula oleh ketaatan satu orang semua orang menjadi orang benar.

Dalam perikop ini, Paulus mengontraskan antara Adam pertama dan Kristus sebagai Adam kedua sebagai representasi umat manusia dan dampak dari tindakan mereka bagi seluruh umat manusia. Konsep kebenaran dan pembenaran yang dinyatakan Paulus dalam perikop ini jelas bersifat forensik sebagai status benar yang dianugerahkan Allah kepada orang berdosa berdasarkan karya Kristus. Hal ini terlihat dari penggunaan kata "penghakiman" dan juga pembenaran sebagai "penganugerahan karunia" di ayat 16. Hal ini diulangi dan dipertegas lagi di ayat 17 yang menyatakan kebenaran sebagai anugerah dan kasih karunia. Berkaitan dengan ayat 16 , Schreiner memberi komentar, "The forensic character of the two terms [penghakiman dan pembenaran] is emphasized here; those who belong to Christ are in the right before God, while those who remain in Adam will be condemned" 46 dan untuk ayat

${ }^{46}$ Ibid., 285. 
17 ia pun mengatakan, "The last term [kebenaran] focuses on the gift of righteousness status before God." ${ }^{77}$ Moo juga memahami kebenaran di ayat 17 sebagai "the status of a new relationship with God." 48

Namun demikian, beberapa indikasi di ayat 17b-19 memperlihatkan bahwa kebenaran dan pembenaran ini lebih dari sekadar bersifat forensik. Penggunaan kata "hidup" dan "berkuasa" di ayat 17-18 serta penggunaan kata "menjadi" di ayat 19 memberi petunjuk bahwa konsep kebenaran dan pembenaran di sini tidak hanya bersifat forensik dan imputasi tetapi juga bersifat etika, transformasional dan impartasi. Kata "menjadi" ( $\kappa \alpha \theta \iota \sigma \tau \alpha \nu \alpha \iota)$ memang menjadi perdebatan di antara para penafsir. Ada yang menafsir kata ini secara forensik "to appoint" atau "to constitute" (menetapkan, mengangkat), namun ada pula yang menafsirkannya sebagai "to make" (membuat, menjadikan). ${ }^{49}$ Dengan melihat konteks penggunaannya di ayat 19, kata ini lebih tepat berarti "menjadikan" karena mereka yang ada di dalam Adam sungguhsungguh menjadi orang berdosa dan mereka yang ada di dalam Kristus sungguh-sungguh menjadi orang benar. ${ }^{50}$ Dengan demikian jelas bahwa arti kebenaran dan pembenaran dalam perikop ini lebih dari sekadar forensik, lebih dari sekadar status benar. ${ }^{51}$ Mengutip Stuhlmacher, Schreiner mengatakan, "This is powerful evidence that righteousness in Paul, although forensic, cannot be confined in every instance to forensic categories." 52 Moo yang teguh memegang pandangan forensik juga harus mengakui bahwa ayat 19 memperlihatkan makna kebenaran yang lebih dari forensik, "In both parts of the verse, then, we are dealing with a real, though 'forensic,' situation: people actually become sinners in solidarity

\footnotetext{
${ }^{47}$ Ibid., 286

${ }^{48}$ Moo, The Epistle to the Romans, 339.

${ }^{49}$ Schreiner, Romans, 288.

${ }^{50}$ Ibid. 199.

${ }^{51}$ Ziesler, The Meaning of Righteousness in Paul, 198-
}

${ }^{52}$ Schreiner, Romans, 288. with Adam—by God's decision; people actually become 'righteous' in solidarity with Christagain, by God's decision." 53

Dari pemaparan di atas dapat disimpulkan bahwa makna kebenaran di dalam perikop ini dipahami Paulus tidak hanya sebagai (1) status benar yang Allah anugerahkan kepada orang percaya karena karya Kristus; namun juga sebagai (2) tindakan Allah yang mengubahkan atau mentransformasi sedemikian rupa sehingga orang percaya yang dinyatakan benar juga sungguh-sungguh menjadi orang benar.

\section{Roma 9:30-10:13}

${ }^{30}$ Jika demikian, apakah yang hendak kita katakan? Ini: bahwa bangsa-bangsa lain yang tidak mengejar kebenaran, telah beroleh kebenaran, yaitu kebenaran karena iman. ${ }^{31}$ Tetapi: bahwa Israel, sungguhpun mengejar hukum yang akan mendatangkan kebenaran, tidaklah sampai kepada hukum itu. ${ }^{32}$ Mengapa tidak? Karena Israel mengejarnya bukan karena iman, tetapi karena perbuatan. Mereka tersandung pada batu sandungan. ... . ${ }^{1}$ Saudara-saudara, keinginan hatiku dan doaku kepada Tuhan ialah, supaya mereka diselamatkan. ${ }^{2}$ Sebab aku dapat memberi kesaksian tentang mereka, bahwa mereka sungguh-sungguh giat untuk Allah, tetapi tanpa pengertian yang benar. ${ }^{3}$ Sebab, oleh karena mereka tidak mengenal kebenaran Allah dan oleh karena mereka berusaha untuk mendirikan kebenaran mereka sendiri, maka mereka tidak takluk kepada kebenaran Allah. ${ }^{4}$ Sebab Kristus adalah kegenapan hukum Taurat, sehingga kebenaran diperoleh tiap-tiap orang yang percaya. ${ }^{5}$ Sebab Musa menulis tentang kebenaran karena hukum Taurat: "Orang yang melakukannya, akan hidup karenanya." "Tetapi kebenaran karena iman berkata demikian: "Jangan katakan di dalam hatimu: Siapakah akan naik ke sorga?", yaitu: untuk membawa Yesus turun, ${ }^{7}$ atau: "Siapakah akan turun ke jurang maut?", yaitu: untuk membawa Kristus naik dari antara orang mati. . . . ${ }^{9}$ Sebab jika kamu mengaku dengan mulutmu, bahwa Yesus adalah Tuhan, dan percaya dalam hatimu, bahwa Allah telah

${ }^{53} \mathrm{Moo}$, The Epistle to the Romans, 346. 
membangkitkan Dia dari antara orang mati, maka kamu akan diselamatkan. ${ }^{10}$ Karena dengan hati orang percaya dan dibenarkan, dan dengan mulut orang mengaku dan diselamatkan. ... ${ }^{12}$ Sebab tidak ada perbedaan antara orang Yahudi dan orang Yunani. Karena, Allah yang satu itu adalah Tuhan dari semua orang, kaya bagi semua orang yang berseru kepadaNya. ${ }^{13}$ Sebab, barangsiapa yang berseru kepada nama Tuhan, akan diselamatkan.

Konteks perikop ini adalah Israel menolak kebenaran Allah yang menyelamatkan. Sementara bangsa-bangsa non-Yahudi mendekat kepada Allah dan dibenarkan karena iman, Israel berusaha menaati hukum Taurat dengan tujuan untuk memperoleh kebenaran dengan usaha mereka sendiri dan bukan dengan iman. Bangsa Israel memiliki hasrat yang kuat untuk Allah tetapi dengan tujuan yang salah, yaitu berusaha membangun kebenaran mereka sendiri daripada menundukkan diri kepada kebenaran Allah. Karena itu, Paulus mengungkapkan argumentasinya bahwa kebenaran karena hukum Taurat secara fundamental bertentangan dengan kebenaran karena iman. Jika mereka yang memegang kebenaran karena hukum Taurat berusaha dengan cara sendiri memperoleh kebenaran maka mereka yang berpegang pada kebenaran karena iman memercayai apa yang telah Allah kerjakan bagi mereka di dalam Yesus Kristus. Dengan demikian, mereka yang menjadi bagian dari umat Allah, baik Yahudi maupun non-Yahudi, percaya kepada berita Injil bahwa Yesus Kristus adalah Tuhan dan Allah telah membangkitkan Dia dari antara orang mati. Kabar baik ini diberitakan secara universal supaya mereka yang percaya kepada nama Tuhan akan diselamatkan.

Makna "kebenaran Allah" di dalam perikop ini (khususnya 10:3) jelas bersifat forensik sebagai status benar yang Allah berikan sebagai anugerah kepada orang percaya. Hal ini terlihat dari disandingkannya kebenaran dengan iman sebagai sarana untuk dibenarkan (9:30, 32; 10:4, 6, 8, 9, 10, 11). Arti kebenaran Allah secara forensik ini juga semakin dipertegas ketika dikontraskan dengan bagaimana
Israel berusaha mendapatkan kebenaran atau mendirikan kebenaran dengan perbuatan mereka sendiri melalui ketaatan kepada hukum Taurat $(9: 32 ; 10: 3)$.

Namun demikian, "kebenaran Allah" di sini juga memiliki arti lebih dari sekadar status benar yang Allah anugerahkan. Hal ini terlihat dari bagaimana Paulus mengutip Ulangan 30:12-14 di pasal 10:6-8. Konteks ayat yang dikutip Paulus adalah Ulangan 29-30 yang berbicara mengenai janji Allah yang akan mencurahkan berkat secara eskatologis (di masa yang akan datang) kepada umat-Nya yang hidup mengasihi dan menaati Dia. Paulus memahami bahwa janji restorasi Allah ini sudah digenapi di dalam Kristus yang menghadirkan masa yang akan datang (era eskatologis), sehingga Paulus bisa berkata bahwa kebenaran itu diperoleh karena iman bukan karena perbuatan menaati hukum Taurat. ${ }^{54}$ Dengan demikian, Paulus juga memahami "kebenaran Allah" di sini sebagai tindakan penyelamatan Allah secara eskatologis sebagai wujud kesetiaan-Nya kepada perjanjian dengan umat-Nya. Dukungan terhadap pemahaman ini semakin dipertegas ketika Paulus memparalelkan "dibenarkan" dengan "diselamatkan" (10:10). Tindakan penyelamatan Allah secara eskatologis ini juga memperlihatkan kuasa Allah yang mentransformasi hati manusia yang dibenarkan-Nya supaya bisa hidup mengasihi dan menaati Dia. ${ }^{55}$ Pemahaman ini juga didukung oleh konteks Ulangan 29-30 yang mencatat janji Allah bahwa di masa eskatologis itu Dia akan menyunat hati umat-Nya supaya mereka bisa mengasihi Tuhan Allah dengan segenap hati dan jiwa mereka (Ul. 30:6).

Dan lebih dari itu, selain berarti status benar dan juga tindakan penyelamatan secara eskatologis yang menyatakan kuasa transformasi Allah, kebenaran Allah di dalam perikop ini juga dapat dimengerti sebagai kesetiaan Allah terhadap perjanjian dengan umat-Nya yang

\footnotetext{
${ }^{54}$ Schreiner, Romans, 557-558.

${ }^{55}$ Makna kebenaran Allah secara etis dalam perikop ini juga didukung oleh Ziesler, The Meaning of Righteousness in Paul, 206-207.
} 
memasukkan orang-orang non-Yahudi sebagai bagian dari umat-Nya. Hal ini terlihat dari konteks perikop ini di dalam kerangka seluruh Roma 9-10 yang memperlihatkan Allah sebagai Allah yang berdaulat dan tidak berpihak, Allah yang adalah Tuhan dari semua orang, baik Yahudi maupun non-Yahudi (9:14-30; 10:12). Bird menyatakan bahwa kebenaran yang berusaha didirikan sendiri oleh Israel berdasarkan hukum Taurat adalah kebenaran yang mereka klaim secara eksklusif sebagai milik mereka sendiri berdasarkan fakta pemilihan Allah, sehingga mereka tidak menyadari ketidakberpihakan Allah yang ditunjukkan baik kepada orang Yahudi maupun nonYahudi. $^{56}$ Karena itu Bird menyimpulkan, "The righteousness at stake here for the gentiles is redemption for sin and death and inclusion in the people of God." 57

Dari penjelasan di atas dapat disimpulkan bahwa konsep kebenaran Allah dalam perikop ini memiliki 3 makna sekaligus, yaitu (1) secara forensik sebagai status benar yang Allah berikan kepada orang percaya yang beriman di dalam Kristus; (2) secara etis sebagai tindakan penyelamatan Allah yang bersifat eskatologis dan digenapi di dalam Kristus serta mengubah hati manusia untuk hidup mengasihi dan menaati Allah; serta (3) secara eklesiologis sebagai kesetiaan Allah kepada perjanjian dengan umat-Nya dengan cara memasukkan orang-orang non-Yahudi sebagai bagian dari umat perjanjian-Nya berdasarkan iman mereka di dalam Kristus.

\section{Kesimpulan}

Dari penggalian terhadap beberapa perikop surat Roma di atas dapat disimpulkan bahwa pemahaman Paulus mengenai kebenaran Allah dipengaruhi oleh konsep kebenaran Allah dari Perjanjian Lama. PL memahami kebenaran Allah sebagai karakter Allah yang benar-adil dan bertindak sesuai dengan karakter-Nya itu untuk menyelamatkan umatNya dan merestorasi seluruh ciptaan sebagai kesetiaan-Nya kepada perjanjian dengan umat-Nya.

Dengan latar belakang pemikiran PL seperti di atas Paulus menafsirkan makna kebenaran Allah di dalam kerangka karya penebusan Kristus yang menggenapkan janji Allah di PL. Sekarang Paulus memahami kebenaran Allah sebagai tindakan penyelamatan Allah secara eskatologis melalui karya penebusan Yesus Kristus, yang menganugerahkan status benar kepada semua orang percaya, baik Yahudi maupun non-Yahudi, yang beriman di dalam Kristus, sebagai wujud kesetiaan-Nya kepada perjanjian dengan umat-Nya. Dengan demikian, konsep kebenaran Allah dari Paulus bersifat utuh dan penuh, baik secara forensik, secara etis maupun secara eklesiologis.

\footnotetext{
${ }^{56}$ Bird, The Saving Righteousness of God, 150.

${ }^{57}$ Ibid., 150-151.
} 


\section{Daftar Kepustakaan}

Bird, Michael F. The Saving Righteousness of God: Studies on Paul, Justification and the New Perspective. Eugene: Wipf \& Stock, 2007.

Campbell, Douglas A. The Rhetoric of Righteousness in Romans 3:21-26. JSNT Supplement Series. Sheffield: JSOT, 1992.

Dunn, James D.G. The Theology of Paul the Apostle. Grand Rapids: Eerdmans, 1998. . WBC: Romans 1-8. Dallas: Word, 1998. Logos Library System.

Fesko, J.V. Justification: Understanding the Classic Reformed Doctrine. Phillipsburg: P\&R, 2008.

Grieb, A. Katherine. The Story of Romans: A Narrative Defense of God's Righteousness. Louisville: WJK, 2002.

Husbands, Mark dan Daniel J. Treier, ed. Justification: What's at Stake in Current Debates. Downers Grove: IVP, 2004.

Johnson, Gary L.W. dan Guy P. Waters, ed. By Faith Alone: Answering the Challenges to the Doctrine of Justification. Wheaton: Crossway, 2006.

Moo, Douglas J. NICNT: The Epistle to the Romans. Grand Rapids: Eerdmans, 1996.

Sanders, E.P. Paul and Palestinian Judaism. Minneapolis: Fortress, 1977.

Schreiner, Thomas R. BECNT: Romans. Grand Rapids: Baker, 1998.

Stendahl, Krister. Paul Among Jews and Gentiles. Minneapolis: Fortress, 1976.

Wilkins, Michael J. dan Terence Paige, ed. Worship, Theology, and Ministry of the Early Church. Sheffield: JSOT, 1992.

Wright, N.T. Justification: God's Plan and Paul's Vision. Downers Grove: IVP, 2009. . What Saint Paul Really Said. Grand Rapids: Eerdmans, 1997.

Ziesler, J.A. The Meaning of Righteousness in Paul: A Linguistic and Theological Enquiry. Cambridge: Cambridge University Press, 2004. 